\title{
Design and Synthesis of 1-Aroyl-2-ylidene Hydrazines under Conventional and Microwave Irradiation Conditions and their Cytotoxic Activities
}

\author{
Lingam Venkata Reddy, ${ }^{a}$ Alishetty Suman, ${ }^{a}$ Syed Sultan Beevi, ${ }^{b}$ \\ Lakshmi Narasu Mangamoori, ${ }^{b}$ Khagga Mukkanti ${ }^{a}$ and Sarbani Pal ${ }^{*, c}$ \\ ${ }^{a}$ Centre for Environment, JNT University, Kukatpally, Hyderabad-500072, India \\ ${ }^{b}$ Centre for Biotechnology, Institute of Science and Technology, Kukatpally, JNT University, \\ Hyderabad-500072, India
}

${ }^{c}$ Department of Chemistry, MNR Degree and PG College, Kukatpally, Hyderabad-500072, India

\begin{abstract}
Reportamos o planejamento e síntese de 1-aroil-2-(alquenil/aril)ideno hidrazinas como moléculas hibridas derivadas do ácido mafenamico e hidrazonas substituídas. Diferentes compostos baseados nesse novo plano foram preparados com bons rendimentos. O intermediário chave, $\mathrm{N}$-acilidrazina, preparado a partir do ácido mafenamico, reagiu com uma variedade de aldeídos, sob condições experimentais convencionais ou com irradiação de microondas. Nesta última, que requer pequenos tempos reacionais, pode-se eliminar o uso de solvente e não é necessário catalisador ácido ou suporte sólido. Alguns compostos sintetisados mostraram atividades citotóxicas in vitro.
\end{abstract}

We report the design and synthesis of 1-aroyl-2-(alkenyl/aryl)idene hydrazines as hybrid molecules derived from mefenamic acid and substituted hydrazones. A number of compounds based on this new scaffold were prepared in good yields. The key intermediate $N$-acylhydrazine, prepared from mefenamic acid, was coupled with a variety of aldehydes under conventional as well as microwave irradiation conditions. The second approach, that requires short reaction time, can be carried out under a solvent free condition and does not require the use of an acid catalyst or solid support. Some of the compounds synthesized showed cytotoxic activities in vitro.

Keywords: mefenamic acid, hydrazine, $N$-acylhydrazine, microwave, solvent-free synthesis, cytotoxicity

\section{Introduction}

Fenamates represent a group of non steroidal antiinflammatory drugs (NSAIDs), e.g. mefenamic acid, tolfenamic acid, flufenamic acid, niflumic acid etc, that belong to $\mathrm{N}$-aryl amino benzoic acid class of compounds. Mefenamic $\operatorname{acid}^{1}$ (1) (Figure 1), one of the most regularly used fenamates for the treatment of pain, is believed to work by blocking the action of (i) cyclooxygenase (COX-1 and COX-2) involved in the production of prostaglandins (that are produced in response to injury or certain diseases and cause pain, swelling and inflammation) or (ii) prostaglandins directly after they have already been formed thereby relieving pain and inflammation. Hydrazones and substituted hydrazones on the other hand continue to attract the attention of the

\footnotetext{
*e-mail: sarbani277@yahoo.com
}

medical researchers, ${ }^{2}$ because of their unique structural feature due to the presence of azomethine hydrogen and a range of pharmacological properties especially antitumoral activities. For example compound 2 (Figure 1) showed promising cytotoxicity ${ }^{3}$ when tested in vitro. In our strategy ${ }^{4}$ to develop safer molecule we decided to combine some of the structural features of mefenamic acid and substituted hydrazones in a single molecule, e.g., 1-aroyl- 2-ylidene hydrazines A (see Figure 2). The

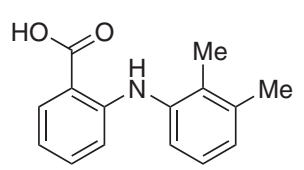

Mefenamic acid (1)

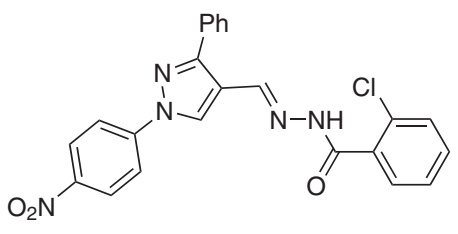

2
Figure 1. Mefenamic acid (1) and substituted hydrazone (2) of pharmacological interest. 


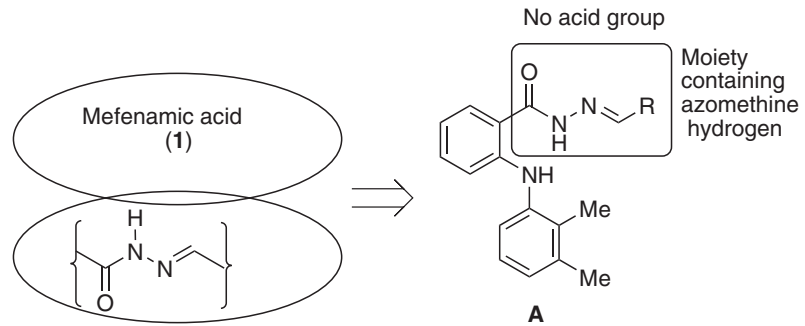

Figure 2. Design of hybrid molecules of potential pharmacological interest.

hybrid molecule A was expected to be cytotoxic due to the presence of hydrazone moiety. Moreover, because of the lack of acid group this molecule was expected to be free from the side effects of $\mathbf{1}$ such as gastrointestinal side effects. Herein, we report the synthesis of a series of mefenamic acid based 2-ylidene hydrazine derivatives of potential biological significances via straightforward condensation of the key intermediate $\mathrm{N}$-acylhydrazine with an appropriate and commercially available aldehyde.

\section{Results and Discussion}

The key intermediate 7 required for our synthesis was prepared from mefenamic acid $\mathbf{1}$ (Scheme 1). Thus, esterification of $\mathbf{1}$ with methanol in the presence of concentrated sulphuric acid followed by the treatment with hydrazine hydrate in methanol gave the compound $\mathbf{7}$ in $75 \%$ yield. Reaction of 7 with 1.1 equivalent of aldehydes (8a-h) in 1,4-dioxane at room temperature afforded the compounds 9a-h (Method A, Scheme 1). During the course of our studies we observed that although aromatic and conjugated aldehydes reacted with the acid hydrazide 7 under conventional method to produce the desired product in good yields, the duration of the reaction, however, was 8-10 h. In order to reduce the reaction time significantly we decided to conduct the reaction of $\mathbf{7}$ with 8a-h under microwave irradiations. Recently organic transformations, under solvent free microwave irradiation conditions,${ }^{5,6}$ has gained extensive applications due to many convenient advantages coupled with superior reaction rates, high yields, improved selectivity and environment friendly reaction conditions. Because of our interest on the development of environmentally benign methods ${ }^{7,8}$ for synthesizing compounds of potential pharmacological significances we conducted the solvent free synthesis of 9 under microwave irradiation. ${ }^{9}$ The solvent free synthesis afforded the desired product $\mathbf{9 a - h}$ within few minutes in excellent yields with a high degree of regioselectivity (Method B, Scheme 1). The results of our study along with the comparison of yields of products obtained via conventional and microwave method has been presented in Table 1.

As shown in Table 1 that a variety of aldehydes including aryl (entries 1-5, 7 and 8, Table 1) and alkenyl (entry 6, Table 1) were employed and yields of products were not affected significantly by the presence of substituents like halo, hydroxyl, alkoxy, amino or aldehyde on the benzene ring. A highly conjugated derivative $9 f$ (entry 6, Table 1) was obtained when 2-butenal was used. The reaction time to prepare $9 \mathbf{a}-\mathbf{h}$ generally varied from 7 to $13 \mathrm{~h}$ for Method A and 1.0 to $2.5 \mathrm{~min}$ in case of Method B. Both the methods produced reaction products in good yields without generating any significant side products. It is therefore, clear that the microwave-mediated method did not differ from the conventional method in terms of product nature. However, it reduced the reaction time remarkably and avoided the use of environmentally harmful organic solvents as well as prolonged heating conditions. Moreover, unlike earlier method ${ }^{9}$ the present microwave-mediated process was free from the use of acid catalyst and solid support. Thus, Method B proved to be more practical and has potential for further use. Notably, synthesis of the same class of compounds from $\mathrm{N}$-acylhydrazine (7) has been reported earlier. ${ }^{10}$ However, this method which involved the reaction of compound 7 with aromatic aldehydes in ethanol in the presence of catalytic amount of $\mathrm{HCl}$ provided the desired products in low to moderate yields (14-76\%, only one compound was isolated in $90 \%$ yield). Moreover, apart from the use of environmentally harmful $\mathrm{HCl}$ this method required longer (0.5-1.0 h) reaction time. Nevertheless, the structures of all the new compounds synthesized were confirmed

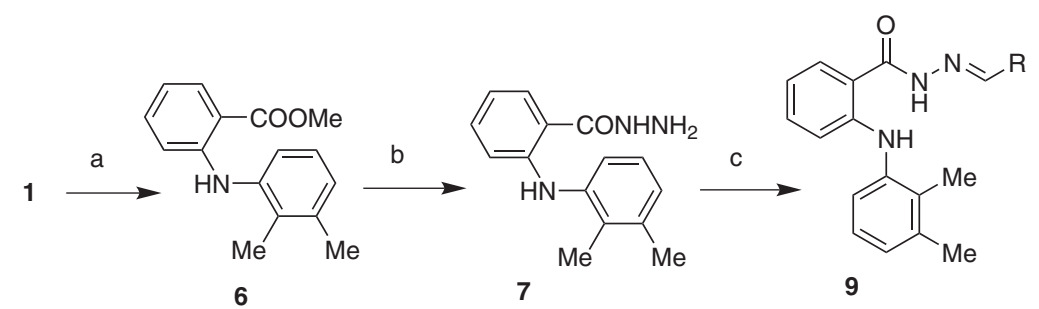

Scheme 1. Synthesis of 1-aroyl-2-(alkenyl/aryl)idene hydrazines (9). Reagents and conditions: (a) $\mathrm{MeOH} / \mathrm{Conc}_{2} \mathrm{H}_{2} \mathrm{SO}_{4}$; (b) $\mathrm{N}_{2} \mathrm{H}_{4} \mathrm{H}_{2} \mathrm{O}$; (c) $\mathrm{Method} \mathrm{A}_{\text {: }}$ RCHO (8) / 1,4-dioxane, rt or Method B: RCHO (8) / MW. 
Table 1. Preparation of 1-aroyl-2-(alkenyl/aryl)idene hydrazines (9) from $N$-acylhydrazine (7) under conventional and microwave irradiation condition

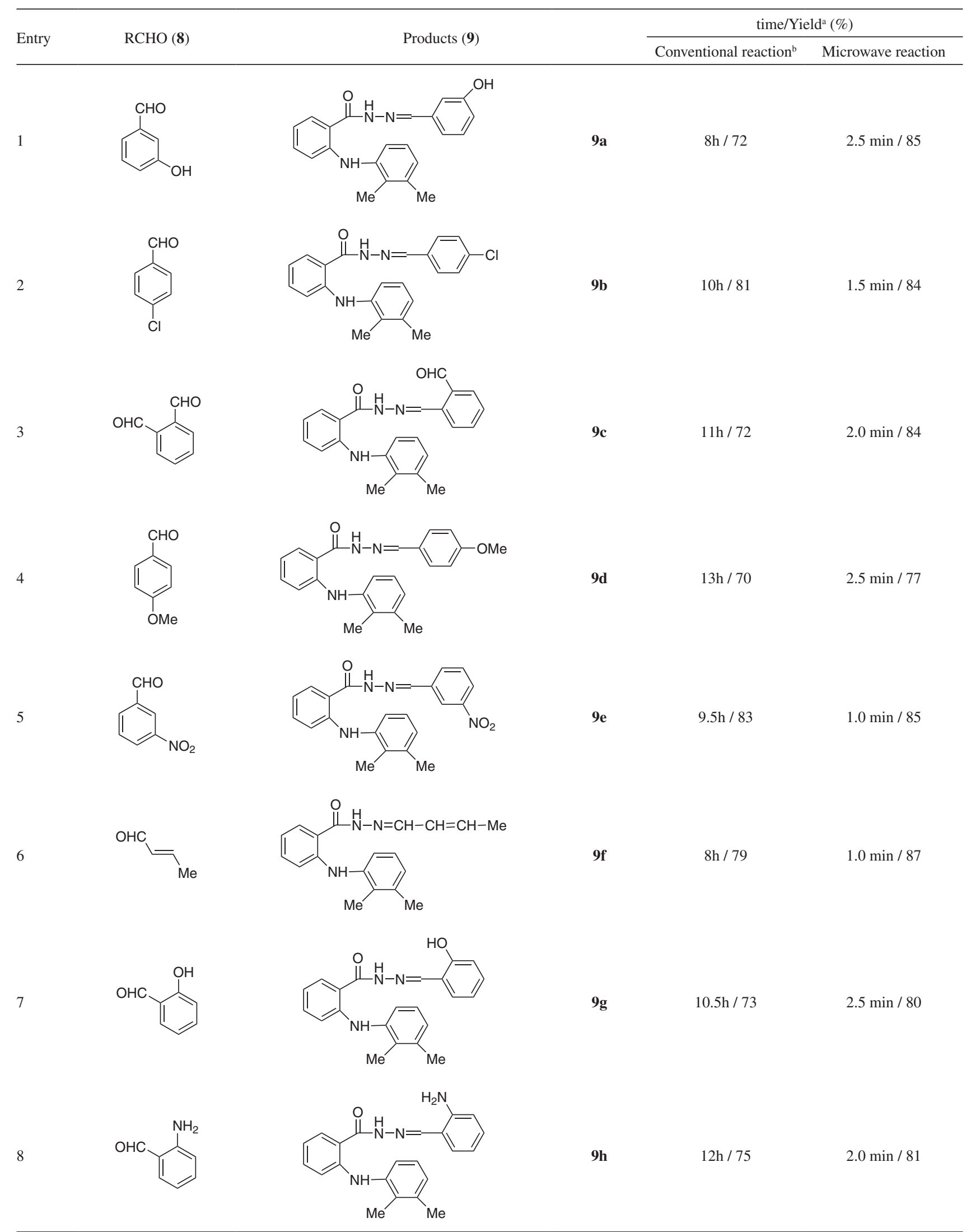

${ }^{\text {a } Y i e l d ~ o f ~ i s o l a t e d ~ p r o d u c t ; ~}{ }^{\mathrm{b}}$ All the reactions were carried out at room temperature. 
Table 2. MTT assay result of ylidene acid hydrazides (9)

\begin{tabular}{lccccccc}
\hline \multirow{2}{*}{ Entry } & Compds. & \multicolumn{5}{c}{ \% of cell death at various doses } \\
\cline { 3 - 8 } & & $1 \mu \mathrm{g}$ & $2 \mu \mathrm{g}$ & $4 \mu \mathrm{g}$ & $6 \mu \mathrm{g}$ & $8 \mu \mathrm{g}$ & $10 \mu \mathrm{g}$ \\
\hline 1 & $\mathbf{9 a}$ & 17.2 & 21.7 & 30.1 & 36.7 & 47.2 & 49.8 \\
2 & $\mathbf{9 b}$ & 18.9 & 20.2 & 24.8 & 25.3 & 31.6 & 32.4 \\
3 & $\mathbf{9 e}$ & 18.1 & 21.7 & 25.3 & 31.6 & 33.5 & $\mathrm{nd}$ \\
4 & $\mathbf{9 f}$ & 27.9 & 29.3 & 31.6 & 33.5 & 33.5 & 34.7 \\
5 & $\mathbf{9 g}$ & 34.8 & 38.1 & 43.6 & 45.7 & 46.1 & 54.1 \\
\hline
\end{tabular}

nd $=$ not done.

by spectral (IR, NMR and MS) and analytical data. The $\mathrm{NH}$ hydrogens and azomethine hydrogens appeared at $\delta 8-12 \mathrm{ppm}$ in the ${ }^{1} \mathrm{H}$ NMR spectra whereas the presence of $\mathrm{C}=\mathrm{N}$ and $\mathrm{C}=\mathrm{O}$ group was indicated by signals at 1580 and $1635-1625 \mathrm{~cm}^{-1}$ in the IR spectra. We attempted to determine the geometry of $-\mathrm{C}=\mathrm{C}-$ of compound 9 f. Based on (i) the nature of the reactant used, i.e., (Z)-but-3-enal and (ii) the $-\mathrm{C}=\mathrm{C}-$ moiety not being the reaction site it is expected that this double bond would maintain the same geometry in the corresponding product. This was supported by the ${ }^{1} \mathrm{H}$ NMR data $(J 8 \mathrm{~Hz})$ of compound 9 .

Some of the compounds synthesized were tested against human lung adenocarcinoma cell line (A549) in vitro to asses their cytotoxic activities and the results are summarized in Table 2. As evident from Table 2, that all the compounds showed moderate cytotoxic activities particularly at higher dose. Compound 9g (Entry 5, Table 2) was found to be the most active in this series followed by 9a (Entry 1, Table 2) indicating the important role played by phenol moiety towards cytotoxic activities.

\section{Conclusion}

In summary, we have described design and synthesis of a variety of novel hybrid molecules, i.e., 1-aroyl-2-(alkenyl/ aryl)idene hydrazines derived from an NSAID, mefenamic acid and pharmacologically active substituted hydrazones. The synthesis of these compounds involves the use of a key intermediate, i.e., $\mathrm{N}$-acylhydrazine that was prepared readily from mefenamic acid following a simple two-step process. Coupling of the acid hydrazide with a variety of aldehydes was studied under conventional as well as microwave irradiation conditions. The second approach showed significant advantages over the previous one by decreasing the reaction time remarkably and avoiding the use of environmentally harmful organic solvents. Due to the lack of acid group and the presence of azomethine hydrogen the present novel class of 1-aroyl-2-ylidene hydrazines is expected to be safer and has potential for further pharmacological evaluation.

\section{Experimental}

\section{General}

Melting points were determined by open glass capillary method on a Cintex melting point apparatus and are uncorrected. IR spectra were recorded on a Perkin-Elmer spectrometer in $\mathrm{KBr}$ pellets. ${ }^{1} \mathrm{H}$ NMR spectra were recorded on a Bruker ACF-300 machine and a Varian $300 \mathrm{MHz}$ spectrometer using DMSO- $d_{6}$, with reference to tetramethylsilane as internal reference. ${ }^{13} \mathrm{C}$ NMR spectra were recorded on a $75 \mathrm{MHz}$ spectrometer. Microwave irradiation was carried out in a domestic micro oven operating at $2450 \mathrm{MHz}$. Elemental analysis were performed by Varian $3 \mathrm{LV}$ analyzer series $\mathrm{CHN}$ analyzer. Mass spectra were recorded on a Jeol JMC D-300 instrument by using Electron ionization at $70 \mathrm{ev}$. All reactions were monitored by TLC on pre-coated silica gel plates. Column chromatography was performed on 100-200 mesh silica gel (SRL, India) using 10-20 fold excess (by weight) of the crude product. The organic extracts were dried over anhydrous $\mathrm{Na}_{2} \mathrm{SO}_{4}$. All solvents were distilled before use. Mefenamic acid (1) and all the aldehydes used are commercially available.

Preparation of methyl 2-(2,3-dimethylanilino) benzoate (6)

To a solution of mefenamic acid $(5.0 \mathrm{~g}, 0.02 \mathrm{~mol})$ in $\mathrm{MeOH}(15 \mathrm{~mL})$ was added conc. $\mathrm{H}_{2} \mathrm{SO}_{4}(1.5 \mathrm{~mL})$ carefully. The solution was refluxed for 16-18 $\mathrm{h}$ and the progress of the reaction was monitored by TLC. After completion of the reaction, solvent was evaporated. The crude was added to water, neutralized by $2 \mathrm{~mol} \mathrm{~L}^{-1} \mathrm{NaOH}$ (until pH is 7.0) and finally extracted with $\mathrm{CHCl}_{3}(3 \times 25 \mathrm{~mL})$. The combined chloroform layer was washed with brine, dried over anhydrous $\mathrm{Na}_{2} \mathrm{SO}_{4}$ and concentrated under reduced pressure. The residue obtained was purified by column chromatography on a silica gel column to afford the desired product as a white solid $\left(4.1 \mathrm{~g}, 80 \%\right.$ yield); $\mathrm{mp} 96-98^{\circ} \mathrm{C}$, $\mathrm{R}_{\mathrm{f}}=0.80$ (3:2 ethyl acetate/n-hexane) MS $m / z 256\left(\mathrm{M}^{+}\right.$, 100\%), 240.1 (M-15); IR $v_{\max } / \mathrm{cm}^{-1}(\mathrm{KBr}): 1686 ;{ }^{1} \mathrm{H}$ NMR 
(DMSO- $\left.d_{6}, 300 \mathrm{MHz}\right) \delta 2.09(\mathrm{~s}, 3 \mathrm{H}), 2.28(\mathrm{~s}, 3 \mathrm{H}), 3.86(\mathrm{~s}$, $3 \mathrm{H}), 6.65-6.72(\mathrm{~m}, 2 \mathrm{H}), 7.05-7.11(\mathrm{~m}, 3 \mathrm{H}), 7.30-7.34(\mathrm{~m}$, 1H), 7.87-7.89 (m, 1H), 9.16 (s, NH); Elemental analysis found $\mathrm{C}, 75.31 ; \mathrm{H}, 6.75 ; \mathrm{N}, 5.33$; Calc. for $\mathrm{C}_{16} \mathrm{H}_{17} \mathrm{NO}_{2}$; C, 75.27; H, 6.71; N, 5.49 .

\section{Preparation of 2-(2,3-dimethylphenylamino)benzo- hydrazide (7)}

To a solution of ester 6 ( $1 \mathrm{~g}, 0.004 \mathrm{~mol})$ in $\mathrm{EtOH}$ $(10 \mathrm{~mL})$ was added hydrazine hydrate $(2 \mathrm{~mL})$ dropwise and the solution was stirred. The temperature of the mixture was raised gradually to $95-100{ }^{\circ} \mathrm{C}$ and was maintained for $12 \mathrm{~h}$. The reaction mixture was then concentrated under reduced pressure and the residue was diluted with water $(10 \mathrm{~mL})$. The aqueous layer was extracted with chloroform $(3 \times 25 \mathrm{~mL})$. The organic layers were collected, combined, washed with brine $(10 \mathrm{~mL})$, dried over anhydrous $\mathrm{Na}_{2} \mathrm{SO}_{4}$ and concentrated under reduced pressure. The solid obtained was purified by crystallization from EtOH, filtered and dried to give the desired compound as a yellow solid (0.82 $\mathrm{g}, 80 \%$ yield); mp $118-120^{\circ} \mathrm{C}, \mathrm{R}_{\mathrm{f}}=0.3$ (3:2 ethyl acetate/n-hexane); MS m/z $256\left(\mathrm{M}^{+}, 100 \%\right) ;{ }^{1} \mathrm{H}$ NMR (DMSO- $\left.d_{6}, 300 \mathrm{MHz}\right) \delta 2.09(\mathrm{~s}, 3 \mathrm{H}), 2.26(\mathrm{~s}, 3 \mathrm{H}), 6.67$ $(\mathrm{d}, J 4 \mathrm{~Hz}, 1 \mathrm{H}), 6.67-7.03(\mathrm{~m}, 3 \mathrm{H}), 7.10-7.25(\mathrm{~m}, 2 \mathrm{H})$, 7.30-7.40 (m, 1H), 7.65-7.68 (m, 1H), $9.0(\mathrm{~s}, 1 \mathrm{H}), 9.40$ (s, 1H), $9.80(\mathrm{~s}, 1 \mathrm{H}), 10.51(\mathrm{~s}, 1 \mathrm{H})$.

Preparation of 1-aroyl-2-(alkenyl/aryl)idene hydrazines $(9 a-g)$

\section{Conventional method (Method A)}

A solution of the compound 7 (2.56 g, $0.01 \mathrm{~mol})$ and compound 8a-g (0.011 mole) in 1,4-dioxane $(15 \mathrm{~mL})$ was stirred at room temperature for the time indicated in Table 1. The progress of the reaction was monitored by TLC. After completion, the reaction mixture was diluted by using ice cold water $(25 \mathrm{~mL})$ with stirring. The solid separated was filtered, washed with ice cold water and recrystallised from EtOH to afford the expected product (9a-g).

\section{Microwave method (Method B)}

A mixture of compound $7(0.01 \mathrm{~mol})$ and aldehydes 8a-g $(0.011 \mathrm{~mol})$ were taken in a $100 \mathrm{~mL}$ beaker and stirred for 5 min to make it homogeneous. The mixture was then exposed to microwave irradiation at $2450 \mathrm{MHz}$ frequency for the time indicated in Table 1 (the reaction was monitored at an interval of $30 \mathrm{~s}$ using TLC). After completion, the mixture was cooled to room temperature and treated with EtOH $(10 \mathrm{~mL})$. The solid separated was filtered and dried to furnish the pure expected product (9a-g). 9a: light green solid; $\mathrm{mp} 218-220^{\circ} \mathrm{C}, \mathrm{R}_{\mathrm{f}}=0.30$ (ethyl acetate/n-hexane, 3:2); MS m/z $360\left(\mathrm{M}^{+}, 100 \%\right) ;{ }^{1} \mathrm{H}$ NMR (DMSO- $\left.d_{6}, 300 \mathrm{MHz}\right) \delta 2.11(\mathrm{~s}, 3 \mathrm{H}), 2.26(\mathrm{~s}, 3 \mathrm{H}), 6.85-$ 6.77 (m, 3H), 7.31-6.93 (m, 7H), 7.71 (d, J $12 \mathrm{~Hz}, 1 \mathrm{H})$, 8.32 (bs, 1H), 9.24 (bs, 1H), 9.63 (s, 1H), 11.81 (s, 1H); ${ }^{13} \mathrm{C}$ NMR (DMSO- $\left.d_{6}, 75 \mathrm{MHz}\right) \delta 13.4,20.1,112.5,114.0$, $115.8,116.7,117.3,118.6,120.0,125.2 ; 125.8 ; 128.8$, 129.5 , 129.7, 132.4, 135.5, 137.6, 138.9, 146.5, 157.6; Elemental analysis found $\mathrm{C}, 73.29 ; \mathrm{H}, 5.75 ; \mathrm{N} 11.35$. Calc. for $\mathrm{C}_{22} \mathrm{H}_{21} \mathrm{~N}_{3} \mathrm{O}_{2} ; \mathrm{C}, 73.52 ; \mathrm{H}, 5.89 ; \mathrm{N}, 11.69$.

9b: white solid; $\mathrm{mp} 196-198{ }^{\circ} \mathrm{C} ; \mathrm{R}_{\mathrm{f}}=0.65$ (ethyl acetate/n-hexane, 3:2); MS m/z $376\left(\mathrm{M}^{+}, 100 \%\right), 378$ $(\mathrm{M}+2)$ in the ratio $3: 1 ; \mathrm{IR} \mathrm{v}_{\max } / \mathrm{cm}^{-1}(\mathrm{KBr}): 1634,1581 ;{ }^{1} \mathrm{H}$ NMR (DMSO- $\left.d_{6}, 300 \mathrm{MHz}\right) \delta 2.10$ (s, 3H), 2.26 (s, 3H), 6.84-6.77 (m, 3H), 6.93-7.31 (m, 7H), 7.72 (d, J $12 \mathrm{~Hz}$, 1H), 8.40 (bs, 1H), 9.23 (bs, 1H), 11.94 (s, 1H); ${ }^{13} \mathrm{C}$ NMR (DMSO- $\left.d_{6}, 75 \mathrm{MHz}\right) \delta 13.4,20.1,114.1,116.7,120.1$, 125.3, 125.8, 128.6, 128.8, 129.6, 132.5, 133.2, 134.4, 137.6, 138.9, 146.3, 146.6, 165.5; Elemental analysis found $\mathrm{C}, 73.61 ; \mathrm{H}, 5.90 ; \mathrm{N}$ 11.41. Calc. for $\mathrm{C}_{22} \mathrm{H}_{20} \mathrm{~N}_{3} \mathrm{OCl}$; C, 73.52; H, 5.89; N, 11.69 .

9c: yellow solid; $\mathrm{mp} 186-188{ }^{\circ} \mathrm{C} ; \mathrm{R}_{\mathrm{f}}=0.56$ (ethyl acetate/n-hexane, 3:2); $\mathrm{MS} \mathrm{m/z} 372\left(\mathrm{M}^{+}, 100 \%\right)$; IR $v_{\max } / \mathrm{cm}^{-1}$ (KBr): 1680, 1625, 1581; ${ }^{1} \mathrm{H}$ NMR (DMSO- $d$, $300 \mathrm{MHz}$ ) $\delta 2.11(\mathrm{~s}, 3 \mathrm{H}), 2.27(\mathrm{~s}, 3 \mathrm{H}), 6.78(\mathrm{t}, J 8 \mathrm{~Hz}, 1 \mathrm{H}), 6.85(\mathrm{~d}, J$ $8 \mathrm{~Hz}, 1 \mathrm{H}), 6.95$ (d, J 6.9 Hz, 1H), 7.07-7.09 (m, 2H), 7.29 $(\mathrm{t}, J 8 \mathrm{~Hz}, 1 \mathrm{H}), 7.52(\mathrm{t}, J 8 \mathrm{~Hz}, 1 \mathrm{H}), 7.75(\mathrm{t}, J 16 \mathrm{~Hz}, 1 \mathrm{H})$, $7.88(\mathrm{~d}, J 6 \mathrm{~Hz}, 1 \mathrm{H}), 8.06-7.90(\mathrm{~m}, 1 \mathrm{H}), 8.10(\mathrm{~m}, 1 \mathrm{H}), 9.17$ $(\mathrm{s}, 1 \mathrm{H}), 9.30(\mathrm{~s}, 1 \mathrm{H}), 12.10(\mathrm{~s}, 1 \mathrm{H})$; Elemental analysis found $\mathrm{C}, 74.49 ; \mathrm{H}, 5.75 ; \mathrm{N}$ 11.09. Calc. for $\mathrm{C}_{23} \mathrm{H}_{21} \mathrm{~N}_{3} \mathrm{O}_{2}$; C, 74.37; H, 5.70; N, 11.31.

9d: white solid; $\mathrm{mp} 210-212^{\circ} \mathrm{C}, \mathrm{R}_{\mathrm{f}}=0.53$ (ethyl acetate/ n-hexane, 3:2); MS m/z $374\left(\mathrm{M}^{+}, 100 \%\right)$; IR $v_{\max } / \mathrm{cm}^{-1}$ (KBr): 1628, 1605, 1576; ${ }^{1} \mathrm{H}$ NMR (DMSO- $d$, $300 \mathrm{MHz}$ ) $\delta 2.11(\mathrm{~s}, 3 \mathrm{H}), 2.27(\mathrm{~s}, 3 \mathrm{H}), 3.80(\mathrm{~s}, 3 \mathrm{H}), 7.07-6.75(\mathrm{~m}$, $8 \mathrm{H}), 7.25-7.30(\mathrm{~m}, 1 \mathrm{H}), 7.63-7.71(\mathrm{~m}, 2 \mathrm{H}), 8.34(\mathrm{~s}, 1 \mathrm{H})$, $9.23(\mathrm{~s}, 1 \mathrm{H}), 11.73(\mathrm{~s}, 1 \mathrm{H})$; Elemental analysis found $\mathrm{C}$, 73.89; $\mathrm{H}, 6.25 ; \mathrm{N}$ 11.77. Calc. for $\mathrm{C}_{23} \mathrm{H}_{23} \mathrm{~N}_{3} \mathrm{O}_{2} ; \mathrm{C}, 73.97$; H, 6.21; N, 11.69.

9e: yellow solid; mp. $216-218{ }^{\circ} \mathrm{C} ; \mathrm{R}_{\mathrm{f}}=0.37$ (ethyl acetate/n-hexane, 3:2); MS m/z $389\left(\mathrm{M}^{+}, 100 \%\right)$; IR $v_{\max } / \mathrm{cm}^{-1}$ (KBr): $1635,1580,1552 ;{ }^{1} \mathrm{H}$ NMR (DMSO- $d, 300 \mathrm{MHz}$ ) $\delta 2.12(\mathrm{~s}, 3 \mathrm{H}), 2.28(\mathrm{~s}, 3 \mathrm{H}), 6.77-7.09(\mathrm{~m}, 6 \mathrm{H}), 7.28-7.30$ $(\mathrm{m}, 1 \mathrm{H}), 7.64-7.83(\mathrm{~m}, 2 \mathrm{H}), 8.06-8.13(\mathrm{~m}, 2 \mathrm{H}), 8.83(\mathrm{~s}, 1 \mathrm{H})$, 9.29 (bs, 1H), 12.21 (s, 1H); Elemental analysis found $\mathrm{C}$, 68.16; $\mathrm{H}, 5.15 ; \mathrm{N}$ 14.25. Calc. for $\mathrm{C}_{22} \mathrm{H}_{20} \mathrm{~N}_{4} \mathrm{O}_{3} ; \mathrm{C}, 68.03$; H, 5.19; N, 14.42 . 
9f: light yellow solid; $\mathrm{mp} 168-170{ }^{\circ} \mathrm{C}, \mathrm{R}_{\mathrm{f}}=0.37$ (ethyl acetate/n-hexane, 3:2); MS m/z308 ( $\left.\mathrm{M}^{+}, 100 \%\right) ; \mathrm{IR} v_{\max } / \mathrm{cm}^{-1}$ (KBr): $1628,1581,1554,1505 ;{ }^{1} \mathrm{H}$ NMR (DMSO- $d_{6}, 300$ $\mathrm{MHz}) \delta 1.87$ (s, 3H), 2.09 (s, 3H), 2.26 (s, 3H), 6.04-6.30 $(\mathrm{m}, 2 \mathrm{H}), 6.73-6.83(\mathrm{~m}, 2 \mathrm{H}), 6.93-7.06(\mathrm{~m}, 1 \mathrm{H}), 7.10(\mathrm{~m}$, $2 \mathrm{H}), 7.26(\mathrm{t}, J 6 \mathrm{~Hz}, 1 \mathrm{H}), 7.63(\mathrm{~d}, J 9 \mathrm{~Hz}, 1 \mathrm{H}), 7.99(\mathrm{~d}, J 8$ $\mathrm{Hz}, 1 \mathrm{H}$ ), 9.20 (s, 1H), 11.53 (s, 1H); ${ }^{13} \mathrm{C}$ NMR (DMSO- $d_{6}$, $75 \mathrm{MHz}) \delta 13.3,18.2,20.1,116.5,117.0,119.9,122.3$, $125.3,125.9,126.7,128.5,128.6,129.5,132.4,138.9$, 146.4, 150.3; Elemental analysis found C, 74.39; H, 6.85; $\mathrm{N}$ 13.60. Calc. for $\mathrm{C}_{19} \mathrm{H}_{21} \mathrm{~N}_{3} \mathrm{O} ; \mathrm{C}, 74.24 ; \mathrm{H}, 6.89 ; \mathrm{N}, 13.67$.

9g: cream solid; $\mathrm{mp} 164-166^{\circ} \mathrm{C} ; \mathrm{R}_{\mathrm{f}}=0.31$ (ethyl acetate/ n-hexane, 3:2); MS m/z $360\left(\mathrm{M}^{+}, 100 \%\right)$; IR $v_{\max } / \mathrm{cm}^{-1}$ (KBr): $1651,1625,1607,1574 ;{ }^{1} \mathrm{H}$ NMR (DMSO- $d_{6}, 300$ MHz) $\delta 2.11(\mathrm{~s}, 3 \mathrm{H}), 2.27$ (s, 3H), 6.76-7.08 (m, 7H), 7.28$7.41(\mathrm{~m}, 2 \mathrm{H}), 7.51(\mathrm{~d}, J 6 \mathrm{~Hz}, 1 \mathrm{H}), 7.74(\mathrm{~d}, J 7 \mathrm{~Hz}, 1 \mathrm{H})$, 8.60 (s, 1H), 9.27 (s, 1H), $11.28(\mathrm{~s}, 1 \mathrm{H}), 12.09$ (bs, 1H); ${ }^{13} \mathrm{C}$ NMR (DMSO- $\left.d_{6}, 75 \mathrm{MHz}\right) \delta 13.5,20.1,116.6,118.6$, $119.2,120.6,121.2,122.1,124.5,125.8,127.8,129.4$, 130.0, 131.2, 133.7, 135.6, 137.6, 138.8, 147.0, 149.0, 157.4, 165.0; Elemental analysis found C, 73.66; H, 5.85; $\mathrm{N}$ 11.55. Calc. for $\mathrm{C}_{22} \mathrm{H}_{21} \mathrm{~N}_{3} \mathrm{O}_{2} ; \mathrm{C}, 73.52 ; \mathrm{H}, 5.89 ; \mathrm{N}, 11.69$.

9h: yellow solid; $\mathrm{mp} 190-192{ }^{\circ} \mathrm{C} ; \mathrm{R}_{\mathrm{f}}=0.53$ (ethyl acetate/n-hexane, 3:2); MS m/z359 (M+1 $100 \%) ; \mathrm{IR} v_{\max } / \mathrm{cm}^{-1}$ (KBr): 1636, 1567, 1523; ${ }^{1} \mathrm{H}$ NMR (DMSO- $d_{6}, 300 \mathrm{MHz}$ ) $\delta 2.12(\mathrm{~s}, 3 \mathrm{H}), 2.28(\mathrm{~s}, 3 \mathrm{H}), 6.57-7.17(\mathrm{~m}, 11 \mathrm{H}), 7.30(\mathrm{t}, J$ $8 \mathrm{~Hz}, 1 \mathrm{H}), 7.82(\mathrm{~d}, J 6 \mathrm{~Hz}, 1 \mathrm{H}), 8.48(\mathrm{~s}, 1 \mathrm{H}), 9.29(\mathrm{~s}, 1 \mathrm{H})$, $11.78(\mathrm{~s}, 1 \mathrm{H}) ;{ }^{13} \mathrm{C}$ NMR (DMSO- $\left.d_{6}, 75 \mathrm{MHz}\right) \delta 16.3,22.9$, $117.5,118.3,120.0,123.1,128.6,129.4,131.3,132.6$, 133.0, 135.1, 136.1, 141.7, 143.9, 149.4, 150.5, 153.8, 167.7; Elemental analysis found C, 73.62; H, 6.25; N 15.69. Calc. for $\mathrm{C}_{22} \mathrm{H}_{22} \mathrm{~N}_{4} \mathrm{O} ; \mathrm{C}, 73.72 ; \mathrm{H}, 6.19 ; \mathrm{N}, 15.63$.

\section{Biological Assay}

Chemical and reagents: Dulbecco's modified eagle medium (DMEM), L-glutamine, streptomycin and penicillin were obtained from Sigma-Aldrich, USA. Foetal bovine serum was procured from PAA Biotech, Germany. All other fine chemicals/reagents used in this study were of cell culture grade and obtained from Sigma-Aldrich and/or Merck.

Cell line and culture conditions: A549 (human lung adenocarcinoma cell line) was obtained from National Centre for Cell Science, Pune, India. The cells were grown in DMEM culture medium supplemented with $2 \mathrm{mmol} \mathrm{L}^{-1} \mathrm{~L}$-glutamine, $10 \% \mathrm{FBS}$, penicillin $(50 \mathrm{IU} / \mathrm{mL})$ and streptomycin $(50 \mu \mathrm{g} / \mathrm{mL})$ at a temperature of $37^{\circ} \mathrm{C}$ in a humidified incubator with a $5 \% \mathrm{CO}_{2}$ atmosphere.
MTT assay for cytotoxicity: The viability of the cells was assessed by MTT (3, 4, 5-dimethylthiazol-2-yl)-2-5diphenyltetrazolium bromide) assay, which is based on the reduction of MTT by the mitochondrial dehydrogenase of intact cells to a purple formazan product (15?). ${ }^{15}$ Cells $\left(1 \times 10^{4}\right)$ were plated in a 96-well plate. After $24 \mathrm{~h}$, they were treated with different concentration $(0-10 \mu \mathrm{g})$ of different test compounds diluted appropriately with culture media for $48 \mathrm{~h}$. Cells grown in media containing equivalent amount of DMSO served as positive control and cells in medium without any supplementation were used as negative control. After the treatment, media containing compound were carefully removed. $100 \mu \mathrm{L}$ of $0.4 \mathrm{mg} \mathrm{mL}^{-1}$ MTT in PBS was added to each well and incubated in the dark for 4 h. $100 \mu \mathrm{L}$ of DMSO was added to each well and kept in an incubator for $4 \mathrm{~h}$ for dissolution of the formed formazan crystals. Amount of formazan was determined by measuring the absorbance at $540 \mathrm{~nm}$ using an ELISA plate reader. The data were presented as percent post treatment recovery ( $\%$ of live cells), whereas the absorbance from non-treated control cells was defined as $100 \%$ live cells.

\section{Acknowledgment}

The author (S. Pal) thanks Mr. M. N. Raju, the chairman of M. N. R. Educational Trust for his constant encouragement.

\section{References}

1. Rawlinson, J. A.; Mefenamic Acid: Some Practical Aspects of the Treatment of Rheumatic Disease, Oxford University Press: UK, 1983, ISBN 0199210438, 9780199210435.

2. Tributino, J. L. M.; Duarte, C. D.; Corrêa, R. S.; Doriguetto, A. C.; Ellena, J.; Romeiro, N. C.; Castro, N. G.; Miranda, A. L. P.; Barreiro, E. J.; Fraga, C. A. M.; Bioorg. Med. Chem. 2009, 17, 1125; Zheng, L.-W.; Wu, L.-L.; Zhao, B.-X.; Dong, W.-L.; Miao, J.-Y.; Bioorg. Med. Chem. 2009, 17, 1957; Vera-DiVaio, M. A. F.; Freitas, A. C. C.; Castro, H. C.; de Albuquerque, S.; Cabral, L. M.; Rodrigues, C. R.; Albuquerque, M. G.; Martins, R. C. A.; Henriques, M. G. M. O.; Dias, L. R. S.; Bioorg. Med. Chem. 2009, 17, 295.

3. Abadi, A. H.; Eissa, A. A. H.; Hassan, G. S.; Chem. Pharm. Bull. 2003, 51, 838.

4. Pal, S.; Bindu, P.; Venna, P. R.; Dubey, P. K.; Lett. Org. Chem. 2007, 4, 292; Pericherla, S.; Mareddy, J.; Rani, D. P. G.; Gollapudi, P. V.; Pal, S.; J. Braz. Chem. Soc. 2007, 18, 384; Jayaselli, J.; Cheemala, J. M. S.; Rani, D. P. G.; Pal, S.; J. Braz. Chem. Soc. 2008, 19, 509.

5. Verma, R. S.; Green Chem. 1999, 1, 43.

6. Kidwai, M.; Mothsra, P.; Ind. J. Chem. Sec. B 2006, 45B, 2330. 
7. Pal, S.; Mareddy, J.; Devi, N. S.; J. Braz. Chem. Soc. 2008, 19, 1207.

8. Pal, S.; Khan, M. A.; Bindu, P.; Dubey, P. K.; Beilstein J. Org. Chem. 2007, 3, 35.

9. For similar reactions on silica gel in the presence of an acid catalyst under microwave irradiation, see: Rostamizadeh, S.; Housaini, S. A. G.; Tetrahedron Lett. 2004, 45, 8753.
10. Almasirad, A.; Tajik, M.; Bakhtiari, D.; Shafiee, A.; J. Pharm. Pharmaceut. Sci. 2005, 8, 419. We thank one of the reviewers bringing this paper to our notice.

Received: May 1, 2009

Web Release Date: October 16, 2009 